\title{
МОДУС КАТЕГОРИЧНОСТІ В СИСТЕМІ ЕКСПРЕСИВНИХ СИНТАКСИЧНИХ ЗАСОБІВ СХІДНОСЛОВ'ЯНСЬКИХ МОВ
}

Козак Р. В. Модус категоричності в системі експресивних синтаксичних засобів східнослов'янських мов.

У статті розглядається модус категоричності як експресивний синтаксичний засіб. Автор висловлює думку, що прагматична спрямованість зближує категоричність з експресивністю, робить їі одним із важливих засобів мовленнєвого впливу. Розкриваються причини підсилення категоричності, жанри, у яких виявляється категоричність, та засоби їі вираження.

Ключові слова: адресат, висловлення, жанр, експресивність, емоційний стан мовця, категоричність, модус, модусний смисл, смислові відтінки категоричності, спілкування.

Козак Р. В. Модус категоричности в системе экспрессивных синтаксических средств восточнославянских языков.

В статье рассматривается модус категоричности как средство экспрессивности. Автор высказывает мысль, что прагматическая направленность сближает категоричность с экспрессивностью, 
делает её важным средством речевого воздействия. Раскрываются причины усиления категоричности, жанры, в которых проявляется категоричность, средства её выражения.

Ключевые слова: адресат, высказывание, жанр, экспрессивность, эмоциональное состояние говорящего, категоричность, модус, модусный смысл, смысловые оттенки категоричности, общение.

Kozak R. V. Modus of categoricity in the system of expressive syntactic means in Eastern Slavonic languages.

In the article the modus of categoricity as an expressive syntactic means is studied. The author suggests that the pragmatic direction brings together the categoricity and expressivity, makes it one of the most important means of verbal influence. The causes of categoricity intensification, its genres and means of its defining are investigated.

Key words: addressee, expression, expressivity, emotional condition of the speaker, genre, categoricity, modus, modus meaning, categoricity and communication shade of meaning.

«Національний менталітет, - як справедливо зауважує Г. Гущина, - має тісний зв'язок із мисленням і світосприйняттям народу, відповідно до якого формуються свідомість і культурні орієнтири та норми, що регулюють поведінку його представників» [3, с. 154], відображають реалії мовної картини світу. У дослідженні мовної картини світу важливе значення має проблема комунікації, що неодноразово висвітлювалось у працях зарубіжних та вітчизняних лінгвістів (Н. Арутюнова, Ф. Бацевич, Н. Гуйванюк, В. Дементьєв, А. Загнітко, Є. Розлогова, Н. Рябцева, Н. Сологуб, Ю. Степанов, С. Проскурін, С. Срмоленко, Л. Чумак, Дж. Лакофф, Г. Клемен, У. Чейф тощо), філософів (П. Рассел, Дж. Серль, Г. Фреге, Л. Вітгенштейн).

Для порівняльного вивчення комунікативно-прагматичної поведінки представників східнослов'янського мовного простору ми обрали прагматичну категорію категоричності висловлення як таку, що багато в чому визначається специфікою національного менталітету і національного характеру українського, російського та білоруського народів. Категоричність - це форма висловлення, що дозволяє партнеру зрозуміти: мовець вважає свою думку істиною останньої інстанції. Категоричність відображає зневагу до думки партнера, її свідоме несприйняття [6].

Упевненість суб'єкта мовлення в міцності своїх морально-етичних, статусно-рольових переконань, у вірогідності висловлюваної інформації, або прагнення чинити емоційний тиск на співбесідника $є$ умовою посилення категоричності судження: Я впевнений, що $X$, підкреслюю, щзо $X$, $i$ хочу, щоб ти це зрозумів. Прагматична спрямованість зближує категоричність з експресивністю. Рівень цієї близькості та відмінностей потребує вивчення, що підкреслює актуальність обраної теми дослідження.

Мета - дослідити семантико-функціональні особливості модусу категоричності як експресивного, синтаксичного засобу в східнослов'янських мовах. Завдання дослідження: 1) визначити місце категорії категоричності серед інших засобів експресивного синтаксису східнослов'янських мов; 2) описати прагмалінгвістичні прийоми та лінгвістичні засоби, що забезпечують експресивність категоричності висловлення, використовуючи як ілюстративний матеріал художні твори українського, російської та білоруської літератури кінця XX - початку XXI століття. 
«Категоричний» у «Словнику української мови» в 11-ти томах тлумачиться як «безумовний, рішучий», а «категоричне судження, лог. безумовне судження» [11, с. 118]. Синонімічними є лексеми категоричний, рішучий, твердий, безапеляційний, беззаперечний, ультимативний, нава́жливий [10, с. 531].

Категоричність - модусна категорія, що уможливлює мовцю жорсткіше чи дипломатично висловити свою думку [14, с. 167]. Т. Шмельова відносить категоричність до соціального метааспекту модусу висловлення, що характеризує відношення між комунікантами [16, с. 30]. Через експресивний характер категоричність стає одним iз важливих засобів мовленнєвого впливу. Наприклад: - Щоб прийшла і уроки зробила // Не подумай іти гуляти (1) // Я зателефоную і перевірю (2) // I не рюмсай (укр.); - Чтоб пришла и уроки сделала // Не вздумай идти на прогулку (1) // Я позвоню и проверю (2) // И не хнычь (рос). Це висловлення і українською, і російською мовою структуроване у формі наказу, що має за мету змусити адресата поводити себе так, як хоче мовець. Авторська експресія виражена агресивною, категоричною формою. Умисна брутальність, категоричність символізують прагнення суб'єкта мовлення посісти позицію «я над іниими». Мовець не до кінця упевнений, що його наказ буде виконаний, тому відчуває негативне емоційно-оцінне ставлення. На поверхневому рівні осуд виявляється в тактиках мовленнєвого впливу із «твердістю про запас»: попередженнях (1) і погрозах (2). Перлокутивний ефект підсилюють дієслова минулого часу доконаного виду із значенням майбутнього, які подають дії адресата так, ніби він уже виконав.

Причини підсилення категоричності, a, відтак, й експресивності висловлення різноманітні. Безапеляційність, панібратство суджень притаманні для домінуючих особистостей. Так вони приховують свою тривогу, чи, навпаки, виявляють зайву самовпевненість. За цієї умови категоричність покликана продемонструвати перевагу мовця перед співбесідником. Категоричність як форма виявлення експресивності залежить від міри залучення суб'єкта до ситуації спілкування, тобто від того, наскільки є актуальним для мовця завдання вплинути на почуття, думки i поведінку співбесідника. За панібратського спілкування категоричність зумовлена щирою прихильністю мовця до співбесідника, його прагненням до співучасті в долі близької людини. Наприклад: Вітольде, ти виростеш жорстоким $і$ злим. Запам'ятай (категоричне попередження). Про иее свідчить не тільки сьогоднішня жорстока бійка на подвір'ї школи, а й твої тонкі губи і примружені хитрі очиці. А тепер геть $з$ моӥх очей, $і$ хай твойй матері стане за тебе соромно... (категорична вимога). Вона ж тебе зовсім не таким виховує (О. Чорногуз); И ты хочешь всё это пустить под хвост своему Марату? Дажне и не вздумай (категоричне попередження), гони этого кретина в шею (категорична вимога), мало тебе, пол жизни, считай, на него угрохала, а 
теперь ещее последние годочки... (Е. Вильмонт); - Сядзі дома! - рашуча спаніла сына Данута (категоричне попередження). - У такой справе дзве бабы лепи за любое войска!.. - Ты, Данута, тут збірайся, а я таксама скокну дахаты ды передачу збяру... (С. Давідовіч).

Насамкінець, категоричність з'являється в мовленні в результаті обрання мовленнєвих тактик із «запасом тривкості»: погрози, докору, попередження, ультиматуму, різкої оцінки, які, як гадає мовець, примусять співбесідника виконати вимогу.

Тип мовленнєвого акту й умови спілкування формують різноманітні смислові відтінки категоричності: рішучість, упевненість, переконаність і власне категоричність, безапеляційність, а також фамільярну відвертість. Перші три відтінки характеризують риторичний образ мовця, який, на думку спеціалістів, забезпечує успіх мовленнєвого впливу. Решта семантичних компонентів мають інтерактивний характер і більше спрямовані на адресата.

Категоричність відображає впевненість адресата у своїй правоті. Упевненість, переконаність і готовність до обстоювання своєї позиції стають причиною експресивності багатьох мовленнєвих жанрів, зокрема, таких як наказ, ствердження, докір, оскаржування тощо. Рівень категоричності перелічених і багатьох інших типів висловлень залежить від ситуації. Лише для небагатьох жанрів категоричність є обов'язковою умовою досягнення мети, постійною характеристикою висловлення, як-от: «вимога», «запевнення», «ультиматум».

Для більшості жанрів східнослов'янських мов категоричність $\epsilon$ змінною величиною, що залежить від низки комунікативно-прагматичних параметрів, основними з яких стають адресат і намір мовця вплинути на його настрій думку і поведінку.

Попри численність жанрів, у яких виявляється категоричність, засоби іiі вираження у східнослов’янських мовах універсальні, можливим стає їх облікування. Категоричність часто має вигляд догми, аксіоми особистої думки, яка не потребує доведення і не може бути запереченою. Тому закономірно, що в категоричних висловленнях функціонують прислів'я, приказки, вислови сентенційного змісту. Наприклад: Кажжый человек жнет то, что сеет. Это жестоко, но это так... (В. Токарева); Його кредо - бери від жсиття все, щчо можсеш. Але - бери найкраще $і$ ти ніколи не залишишся в програші (О. Чорногуз); - Хай здохне той, хто нас ня любіць! - абвяшчаў ен... (Н. Бабіна).

Для мовленнєвих жанрів, що цілеспрямовано погіршують взаємовідносини комунікантів, типовими є розмаїті глобальні узагальнення, які, на нашу думку, не можна кваліфікувати як сентенції. Наприклад: Что я, слова сказать не имею? - Не имеешь. Ты вообще ни на что не имеешь никакого права. Потому что ты никто, ничто и звать тебя никак (В. Токарева); Пам'ятай! Ти своїми зубами копаєш собі яму! 
(О. Чорногуз); - Сам змей ачковы! - агрызнуўся Ціхан. - Капелюшовы акулярык! - I, задаволены сабой, вярнуўся да сваіх вудай (С. Давідовіч). Якщо комуніканти з'ясовують відносини, то мовець для підсилення своєї позиції видає власну думку за загальну, якій, як відомо, важко суперечити через «всезагальність» і «безособовість». У цьому категоричність взаємодіє 3 експресивною модусною категорією інтенсивності, що забезпечує, за Т. Шмельовою, «ефект генеральності» [17, с. 22] чи глобальності.

Інколи категоричність пояснюється прагненням мовця підсилити мовленнєвий вплив на партнера. Для цього він намагається «обважнити» фразу, зробити іiі більш значущою. Найпоширенішим прийомом реалізації цього завдання є парцеляція, часто з риторичним прийомом градації, що притаманно для усіх східнослов'янських мов: Чтобы его не было. Никогда. Никому (В. Токарева); А потім в очах стало темно, бо темна вода поглинула його. Назавюди (А. Кокотюха); - Давай усю вёску збярэм сюдьь! Ніякіх Толікаў! Сам датумкаю, не сумнявайся! (С. Давідовіч).

Роль парцелятів в усіх східнослов'янських мовах виконують слова iз значенням охоплювання, глобальної характеристики явища чи iз семантикою тотального заперечення: абсолютно, завжди, весь, щуохвилини; ніде, ніколи, ні за щзо, ні для чого тощо. Наприклад: - А дома он будет сидеть? - забеспокоилась Эльга. - Всю жнзнь, - убеждённо сказала Люся (В. Токарева); - Не за неї, - повторив він. - Тебе люблю. Тебе, Роксано. Всю. До краплиночки (О. Чорногуз); I карасям са шчупакамі, вёрткім уюнам ды непаваротлівым ракам тут не вытыцьь. Аніяк (А. Казлоў). До цього ж відносимо різноманітні інтенсифікатори, як-от: - Нa cmo процентов, - убеждённо соврала Лена. - Дажке на сто один (В. Токарева); - Петро Петрович! Петро Петрович! - назвався, звертаючись до кожного. - Дуже, дуже приємно! Зараз негайно - за стіл! Негайно і без заперечень! (І. Роздобудько); Сама Марыля з суседняй вёскі-Cвінчова. Нават не з Свінчова, а з хутара Салаўй, што стаяў на ўзлессі, паблізу ад вёскі (У. Гніламёдаў).

Поширеним засобом підсилення категоричності у східнослов'янських мовах є повтори. Наприклад: - Tbl поедешь... - не верю я. - Нет, поедем, поедем, поедем, - страстно проговорила Алка (В. Токарева); - A тому, щуо, запевняю вас, ніхто - чуєте - ніхто! - не відмовиться (І. Роздобудько); - Цяпер была б такой. Была б (А. Казлоў).

Через категоричність автор установлює своє право на висловлення в певному жанрі, як-от: поради чи докору. Він підкреслює свою відповідальність і авторитетність висловленої думки: «Я сказав, щуо $X$, значить X»; «Я сказав!»; «Я сказав, і все (крапка, гаплик)!»; «Я все сказав!».

Зустрічаємо й інші варіанти, як-от: Миша! Kуда mbl лезешь, паршивец! Вернись обратно сию же минуту, - кричал женский голос. Ты сльишишь, что я тебе сказала? (В. Токарева); Такого я більше не потерплю $і$ не прощу... Я більше тебе не хочу бачити у цъьому домі, - 
верещала Альбіна (О. Чорногуз); - Пазбіраеще вы ияпер мае грыбкі! Ой пазбіраеце! - трыумфаваў ен. - Так пазбіраеце, што не будзець паспяваць мяняць штаны на бягу! (С. Давідовіч). Такі конструкції виражають безапеляційність судження, нерівноправні рольові відносини у діалозі: один співбесідник висловлює думку, а інший має безсуперечно взяти іiї до уваги. Категоричні висловлення позначають узурпацію мовцем права на мовлення. Діалог стає монологом, що порушує принцип комунікативного співробітництва.

Експресивність категоричних висловлень підтримують підсилювальні частки. Наприклад: Надо же так вляпаться!.. Да ещё муж этот гребаный! И шантаж... (Т. Устинова); Ні. Проте хай вас ие не турбує. Ваша присутність навряд чи буде дуже помітною, а, отже, $i$ відсутність не дуже помічатимуть (А. Кокотюха); Нi ў чым і ніколі не сумнявайся. Будзь ивірдай, як каменная глыба. Ты ж не з слабахрыбетных. Не вінаградны смоўж, што пакідае пасля сябе колькі слізь. Ты носьбіт справядлівай помсть!! (А. Казлоў).

Важливим засобом оформлення категоричного висловлення у східнослов'янських мовах $\epsilon$ інтонація. На ії характер вказують авторські ремарки в художньому тексті і прислівники різко, переконливо, впевнено, агресивно, войовниче, твердо, пристрасно, з притиском тощо. Певне уявлення про інтонацію отримуємо 3 дієслів, що називають тип мовленнєвого акту: наказати, скомандувати, розпорядитися, вимагати, запевнити, підтвердити. Із переліку бачимо, що авторський коментар невербального супроводу категоричного висловлення досить обмежений, оскільки найчастіше для адекватної інтерпретації мовленнєвого акту достатньо словесної частини висловлення. Інша причина лаконізму полягає в тому, що припредикатні визначники (переконано сказав, пристрасно заговорив), мабуть, подають читачеві необхідне уявлення щодо невербальної поведінки суб'єкта мовлення.

Категоричність знаходить своє вираження і в невербальних засобах: міміці, рухах рук мовця. Жорсткість позиції спричиняє напругу м'язів обличчя, і воно стає «твердим». Голова тоді знаходиться у стані «президента» (відкинута назад і трохи нахилена вбік) або «агресора» (підборіддя опущено до грудей і погляд «спідлоба» спрямований на співбесідника) [8, с. 102]. Губи стиснуті. Малорухоме обличчя символізує неухильне переконання у правильності поведінки та рішучість у захисті своєї позиції. Мабуть, міміка дуже вражає співбесідника, пригнічує його волю і попереджує зворотну мовленнєву поведінку. Невербальних сигналів категоричності небагато, але вони можуть стати об'єктом окремого вивчення.

Розгляд висловлень, експресивність яких досягається у східнослов'янських мовах через підсилення категоричності і характеризується певними спільними ознаками, уможливлює висновок, що категоричність у 
семантичному плані $\epsilon$ неоднорідною: може виявлятися в конкретному мовленнєвому акті як упевненість, переконаність, рішучість чи безапеляційність, некоректність чи фамільярна відвертість. Підсилення категоричності залежить від емоційного стану мовця, його потреби вплинути на думку i поведінку партнера, від статусно-рольових взаємовідносин комунікантів, від мети і завдань комунікації. Необхідно підкреслити діалогічну спрямованість аналізованого модусного смислу: категоричні висловлення обмежують узвичаєну зміну ролей у діалозі.

Модус категоричності як експресивного синтаксичного засобу, безумовно, характеризується і певною національною специфікою української, російської та білоруської мов, що стане об’єктом дослідження в подальших статтях.

\section{Література}

1. Бабіна Н. Рыбін горад : раман / Наталка Бабіна. - Вільня : Інстытут беларусістыкі, 2007. - 312 с. - («Кнігарня «Наша Ніва»).

2. Гніламёдаў У. Уліс з Прускі : раман / Уладзімір Гніламёдаў. - Мінск : Маст. літ., 2006. - 382 с. (Беларуская проза XXI стагоддзя).

3. Гущина Г. И. Актуализация категории категоричности / некатегоричности высказывания в языковой картине мира [Текст] / Г. И. Гущина // Современная филология : материалы междунар. заоч. науч. конф. (г. Уфа, апрель 2011 г.) / под общ. ред. Р. Д. Ахметовой. - Уфа : Лето, 2011. - С. 154-157.

4. Давідовіч С. Ф. Развод па-славянску : апавяданні, аповесці / Сяргей Давідовіч. - Мн. : Маст. літ., 2005. -358 c.

5. Казлоў А. С. Аргон : раманы, аповесці, апавяданні / Анатоль Казлоў. - Мінск : Маст. літ., 2006. 255 с. - (Беларуская проза XXI стагоддзя).

6. Категоричність // http: // www.sinton.ru/kategorichnost.htm.

7. Кокотюха А. Темна вода. Роман / Андрій Кокотюха. - К. : Нора - Друк, 2006. - 260 с.

8. Панасюк А. Ю. Вам нужен имиджмейкер? / А. Ю. Панасюк. - М. : Экономика, 2000. - 272 с.

9. Роздобудько І. Дві хвилини правди. Роман / Ірен Роздобудько. - К. : Нора - Друк, 2008. - 248 с. (День Свропи).

10. Словник синонімів української мови : у 2-х т. / А. А. Бурячок, Г. М. Гнатюк, С. І. Головащук та ін. - К. : Наук. думка, 1999-2000. - Т. 2. - 960 с.

11. Словник української мови : в 11-и т. - К. : Наук. думка, 1970-1980. - Т. 4. - 840 с.

12. Токарева В. С. Перелом : повесть, рассказы / В. С. Токарева. - М. : АСТ, 1999. - 471 с.

13. Устинова Т. В. Близкие люди : роман / Татьяна Устинова. - М. : Эксмо, 2010. - 384 с.

14. Химик В. В. Категория субъективности и её выражение в русском языке / В. В. Химик. - Л. : Изд-во Ленингр. ун-та, 1990. - 184 с.

15. Чорногуз О. Ф. Дари пігмеїв / О. Ф. Чорногуз. - К. : Видавничий центр ВУС, 2005. - 240 с.

16. Шмелёва Т. В. Субъективные аспекты русского высказывания : дисс. в виде науч. доклада на соис. учён. ст. доктора филол. наук / Т. В. Шмелёва. - М. : Изд-во МГУ, 1995. - 35 с.

17. Экспрессивность на разных уровнях языка : сб. науч. трудов. - Новосибирск : НГУ, 1984. - 160 с. 